\title{
Nature and incidence of peripheral nerve syndromes in HIV infection
}

\author{
Geraint N Fuller, Jean M Jacobs, Roberto J Guiloff
}

\begin{abstract}
Fifty four patients with peripheral nerve syndromes were seen during a 15 month period in a population of about $1500 \mathrm{HIV}$ infected patients at all stages of the disease. Distal symmetrical peripheral neuropathies were seen in 38 of the 54 patients, (11.5\% of AIDS patients) and could be distinguished into two forms. The most common $(n=25)$ was a painful peripheral neuropathy during AIDS, which is distinct clinically and pathologically, having axonal atrophy, and is associated with cytomegalovirus infection at other sites. The 13 non-painful neuropathies seen were more heterogenous. Lumbosacral polyradiculopathy associated with cytomegalovirus and lymphomatous mononeuritis multiplex occurred in fewer than $1 \%$ of AIDS patients. Mononeuropathies were seen in $3 \%$ of AIDS patients. No patients with acute or chronic inflammatory demyelinating polyradiculoneuropathies were seen. The annual incidence of neuropathies during the AIDS related complex stage was less than 1\%; none were seen in asymptomatic HIV seropositive patients.
\end{abstract}

(F Neurol Neurosurg Psychiatry 1993;56:372-381)

A variety of peripheral nerve syndromes have been described at different stages of HIV infection, from seroconversion to AIDS. Most described are case reports or small selected series which do not estimate the incidence. A large prospective study of HIV positive patients found that peripheral neuropathies were rare', and a cross sectional study of 40 hospitalised patients with AIDS found that $33 \%$ had peripheral neuropathies.' We report the nature and frequency of peripheral nerve syndromes seen during a 15 month prospective, population based, referral series from a population of about $1500 \mathrm{HIV}$ positive patients ${ }^{3}$ and discuss the findings in relation to current classifications of peripheral nerve syndromes.

\section{Methods}

PATIENTS

Patients were included if they had been referred to the neurology department with peripheral nerve syndromes between 1 September 1988 and 31 December 1989 from the population of HIV infected patients who attended hospitals and clinics in the East Riverside area. Patients were excluded if they had been exposed to neurotoxins (drugs such as vincrinstine, isoniazid, or thalidomide or regularly took more than 40 units of alcohol a week) or had other systemic conditions, not related to HIV, associated with peripheral neuropathy (such as diabetes or uraemia) or had a family history of peripheral neuropathy. Patients were classified as having AIDS according to the CDC criteria'; they were classified as having AIDS related complex if they were HIV positive and had persistent generalised lymphadenopathy, fever, oral hairy leukoplakia, oral candidiasis, herpes zoster radiculitis, and foliculitis but lacked AIDS defining opportunistic infections or tumours. At the time of the study the neurotoxic nucleoside analogues DDI and DDC were not being used.

At the start of the study (September 1988) 1353 HIV positive patients were being followed up at these clinics. A total of 748 had AIDS related complex and 261 had AIDS (C Dalton, personal communication). By September 1989 there were 1765 HIV positive patients, of whom 778 had AIDS related complex and 297 had AIDS. Of the HIV positive patients, $83 \%$ were homosexual or bisexual, $4.4 \%$ were drug misusers, and $2.5 \%$ were heterosexual and did not misuse drugs. For $10 \%$ the risk factors were unknown. There were no haemophilics. Between September 1988 and 1 September 1989, 105 patients died with AIDS in this population.

Patients were assessed with a standardised neurological examination. The five found to have bilateral upper motor neuron signs at presentation of peripheral neuropathy will be considered separately to allow the clinical features of the neuropathy to be studied in isolation. The following HIV related and nutritional data were collected in a standardised way: duration of AIDS, previous HIV related infections (using CDC criteria ${ }^{+}$), CD4 count (ACSCAN TM, Becton Dickinson), body mass index (weight divided by height squared), serum B-12 concentration (DICOPAC radioimmunoassays; normal range $210-900 \mathrm{pg} / \mathrm{ml}$ ), and serum albumin concentration. The same data were collected for the neurologically asymptomatic AIDS controls and the series of sequential patients with AIDS admitted to hospital (see below).

Patients were classified according to the stage of the disease and the pattern of the peripheral nerve syndrome (distal symmetrical peripheral neuropathy, mononeuritis mul- 
tiplex, polyradiculopathy, or mononeuropathy). The distal symmetrical peripheral neuropathies were distinguished as those with pain and those without. Pain was defined as an unpleasant sensory experience subjectively recognised by the patient and mentioned in the history. No formal pain scale was used. This distinction is further considered in the discussion.

Standardised electrophysiological studies and pathological studies of the sural nerve were performed using previously described methods. $^{57}$

\section{CONTROL GROUPS}

Neurologically asymptomatic AIDS patientsPatients with AIDS but without signs or symptoms of peripheral neuropathy were assessed clinically $(n=30)$ and were studied electrophysiologically $(n=30)$ and pathologically $(n=5)$. Data related to HIV and nutrition were noted as described above. The group has previously been described in detail $^{7}$ and it provided electrophysiological and pathological control data (see table 4).

Patients with AIDS admitted to hospital sequentially $(\mathrm{n}=30)$ were assessed separately and the standardised HIV related data were collected. This data has been published previously. ${ }^{8}$ Sequential patients, with or without neuropathies, were recruited to determine the frequency of different opportunistic infections in patients with AIDS from the population under study, unselected in relation to their neurological symptoms (see tables 1 and 2).

Sudden death controls - The sural nerves from eight patients (mean age 42 (range 21-58) years) without risk factors for HIV infection and without history of peripheral neuropathy, all of whom died suddenly, were examined morphometrically and used as controls for pathological data. They have been described previously. ${ }^{57}$

Normal controls-Nerve conduction studies have been carried out on 23 healthy men age matched (mean $31.2(21-45)$ years) with the neurologically asymptomatic AIDS patients; the results (see table 4 ) have been published previously. $^{7}$
STATISTICS

Normally distributed variables were compared by using one sample Student's $t$ test. Non-normally distributed variables were compared by using the Mann-Whitney $U$ test. Proportions were compared by using the two tailed Fisher's exact test. All statistics were performed with the Statgraphics statistical package (STSC Plusware, 1987).

\section{Results}

Fifty four patients with peripheral nerve syndromes were seen. All were male. Thirty eight had distal symmetrical peripheral neuropathies; $25(66 \%)$ of these were painful, 13 painless. Eleven patients had mononeuropathies, three had mononeuritis multiplex, and two had lumbosacral polyradiculopathy. Table 1 gives the HIV and nutritional variables for the control groups and for the patients with distal symmetrical peripheral neuropathies.

\section{PAINFUL PERIPHERAL NEUROPATHIES}

Twelve of 25 patients with painful peripheral neuropathies (PPN) were reported on previously. ${ }^{8}$ The variables related to HIV infection and nutrition are given in table 1 and the preceding infections in table 2. The duration of AIDS, CD4 count, body mass index, albumin concentration and percentage of patients with abnormal vitamin $\mathbf{B}_{12}$ did not differ from those in the control groups. Five patients had clinical evidence of an associated myelopathy.

\section{Clinical features}

Pain was the most prominent symptom, commonly described as burning $(10 / 20)$ or intense pins and needles $(9 / 20)$. Two patients referred to it as frostbite and one as having the soles of his feet beaten with bamboo sticks. Four patients with painful dysaesthesia also had shooting pains to the feet. The pain was almost always made worse by contact $(19 / 20)$, often by as little as the weight of the sheets on the bed. Most patients had to stop wearing their normal shoes and usually had to resort to slippers. One patient became wheel-

Table 1 HIV infection and nutrition in patients with peripheral neuropathies and controls with AIDS

\begin{tabular}{|c|c|c|c|c|}
\hline & \multirow[b]{2}{*}{$\begin{array}{l}\text { Patients with } \\
P P N \\
(n=25)\end{array}$} & \multicolumn{2}{|c|}{ Controls with AIDS } & \multirow[b]{2}{*}{$\begin{array}{l}\text { Patients with } \\
\text { OPN } \\
(n=13)\end{array}$} \\
\hline & & $\begin{array}{l}\text { Sequential } \\
\text { admissions } \\
(n=30)\end{array}$ & $\begin{array}{l}\text { Neurologically } \\
\text { asymptomatic } \\
(n=30)\end{array}$ & \\
\hline Mean(SD) age (years) & $36(6 \cdot 5)$ & $40(9 \cdot 4)$ & $37(9 \cdot 1)$ & $41(7 \cdot 3)$ \\
\hline \multirow{2}{*}{$\begin{array}{l}\text { HIV infection: } \\
\text { Median (interquartile range) } \\
\text { duration of AIDS } \\
\text { Median (interquartile range) } \\
\text { CD4 count ( }(\mu \mathrm{l})\end{array}$} & $11 \cdot 0(3-17)$ & $14 \cdot 0(3-23)$ & $11 \cdot 5(3-20)$ & $12 \cdot 5(3-24)$ \\
\hline & $4 \cdot 0(7-21)$ & $18 \cdot 5(10-40)$ & $20 \cdot 5(10-68)$ & $12 \cdot 0(6-25)$ \\
\hline \multirow{3}{*}{$\begin{array}{l}\text { Nutritional indicators } \\
\text { Mean }(\mathrm{SD}) \text { body Mass Index } \\
\left(\mathrm{kg} / \mathrm{m}^{2} ; \text { normal range } 21 \cdot 3-29 \cdot 0\right) \\
\text { Mean }(\mathrm{SD}) \text { albumin concentration } \\
(\mathrm{g} / \mathrm{l} ; \text { normal range } 35-45 \mathrm{~g} / \mathrm{l}) \\
\% \text { of patients with abnormal } \\
\text { serum } \mathrm{B}-12\end{array}$} & $19 \cdot 3^{\star}(2 \cdot 8)$ & & $19 \cdot 9^{\star \star}(2 \cdot 1)$ & $17 \cdot 3(2 \cdot 5)$ \\
\hline & $34(5 \cdot 6)$ & & $34(5 \cdot 9)$ & $35(5 \cdot 4)$ \\
\hline & $8 \cdot 3$ & & 24 & $4(31)$ \\
\hline
\end{tabular}

PPN = painful peripheral neuropathy; OPN = other (non-painful) peripheral neuropathy.

${ }^{\star} p<0.02 v$ other (non-painful peripheral neuropathy).

${ }_{\star \star} \mathrm{p}<0.005 v$ other (non-painful peripheral neuropathy) 
Table 2 Percentage of prior and current infections in patients with painful peripheral neuropathy (PPN), non-painful peripheral neuropathy (OPN) and controls with AIDS.

\begin{tabular}{|c|c|c|c|c|}
\hline & \multirow[b]{2}{*}{$\begin{array}{l}\text { Patients with } \\
\text { PPNt } \\
(n=22)\end{array}$} & \multicolumn{2}{|c|}{ Controls with AIDS } & \multirow[b]{2}{*}{$\begin{array}{l}\text { Patients with } \\
\text { OPN } \\
(n=13)\end{array}$} \\
\hline & & $\begin{array}{l}\text { Sequential } \\
\text { admissions } \\
(n=30)\end{array}$ & $\begin{array}{l}\text { Neurologically } \\
\text { asymptomatic } \\
(n=30)\end{array}$ & \\
\hline Pneumocystis carinii pneumonia & 69 & 67 & 70 & 69 \\
\hline $\begin{array}{l}\text { Cytomegalovirus: } \\
\text { Any site } \\
\text { Retinitis } \\
\text { Gastrointestinal } \\
\text { Pneumonitis } \\
\text { Kaposi's sarcoma } \\
\text { Visceral candidiasis } \\
\text { Cryptosporidiosis } \\
\text { Toxoplasmosis } \\
\text { Lymphoma } \\
\text { Cryptococcal meningitis } \\
\text { Mycobacterium avium intracellulare infection }\end{array}$ & $\begin{array}{l}78^{\star \star} \\
46 \\
18 \\
23 \\
32 \\
19 \\
0 \\
6 \\
6 \\
9 \\
4\end{array}$ & $\begin{array}{r}37 \\
27 \\
10 \\
6 \\
27 \\
20 \\
17 \\
13 \\
0 \\
0 \\
3\end{array}$ & $\begin{array}{r}40 \\
23 \\
20 \\
3 \\
27 \\
23 \\
17 \\
13 \\
3 \\
3 \\
0\end{array}$ & $\begin{array}{r}31 \\
8 \\
23 \\
8 \\
46 \\
15 \\
15 \\
0 \\
0 \\
0 \\
31^{\star}\end{array}$ \\
\hline
\end{tabular}

chair bound because of extreme contact pain. The pain was limited to the legs in all but two patients, mostly affecting the feet $(n=17)$. It was limited to the toes in two patients and to the soles in one. One patient had low back pain at the onset. The symptoms were symmetrical in all but four patients.

The onset of pain was subacute, usually beginning with stiffness in the toes, later progressing to become painful. Maximum pain usually occurred within two to four weeks $(13 / 20)$; in one patient the pain reached its peak in less than a week; in another it took over two months. The pain usually improved spontaneously (in eight patients it resolved completely) but in six patients it persisted unchanged. One patient had recurrence of pain followed by further improvement. Some symptomatic relief was obtained with carbamazepine in seven patients and amitriptyline in eight, but both drugs failed to help in one instance. Two patients reported that marijuana alleviated the pain. Two patients had Kaposi's sarcoma in the feet but it was thought unlikely to be the cause of the pain as neither the site nor the time course of the pain matched that of the Kaposi's sarcoma.

All patients complained of numbness, which was again mostly in the feet $(17 / 20)$, to mid-calf in one patient, only in the toes in one, and in the soles in another. Three patients noted numbness in their fingertips. Paraesthesia was felt in the feet in 13, to midcalf in one, in the toes in one, and the fingertips in two. No patients complained spontaneously of weakness. Three patients had observed their toes moving spontaneously, an observation confirmed in two. In two patients, mononeuropathies had been the first indication of peripheral nerve dysfunction (meralgia paraesthetica in one and a probable common peroneal palsy in the other). A further patient had an episode of meralgia paraesthetica six months before the onset of his pain. Half the patients had noted that they became impotent at the onset of pain; in only two was this volunteered spontaneously. A further three noted urinary symptoms; one had difficulty with micturition and two had frequency.

Distal weakness with wasting of extensor digitorum brevis was found in five of 20 patients. In a further patient, distal weakness developed 10 months after the onset of pain. At the first assessment the ankle reflexes were normal in 10, impaired in five, and absent in five. There was a progressive loss of ankle reflexes, with the reflex being absent at the final assessment in 14 patients and impaired in three. No patient had distal lower limb oedema.

Sensory abnormalities were predominantly of superficial sensation. All patients had alteration of light touch or pinprick (loss of light touch in 12 and pinprick in 15). Subjective changes extended to the ankle while the loss was usually in the toes. In all but three patients the changes were limited to the legs. In these three the loss in the arms was restricted to the fingertips in two and to the little finger in one. Temperature sensation was altered in 15; vibration sense was abnormal in 15 but only to the level of the toes. Position sense was impaired at the toes in six. In eight, the sensory signs did not alter. In 10 there were changes: improvement in two, a deterioration in eight. The change was slight with the exception of those patients who were initially assessed within one or two weeks of the onset of their symptoms.

The clinical features of patients with peripheral neuropathies are summarised in table 3. The clinical features of the five patients who also had signs of a myelopathy at presentation were similar, but in addition they had bilateral pyramidal weakness and pathologically brisk reflexes in the arms and at the knee. The ankle reflexes were abnormal in all five at presentation.

Twenty three patients were followed up until death (median 7 months, range 1-21 months); two were alive at review at 10 and 14 months. 
Table 3 Clinical features of patients with painful (PPN) and other peripheral neuropathies (OPN) without evidence of myelopathy, values are numbers of patients

\begin{tabular}{|c|c|c|c|}
\hline & $\begin{array}{l}P P N^{\circ} \\
(n=20)\end{array}$ & $\begin{array}{l}O P N^{\circ} \\
(n=9)\end{array}$ & $p$ value \\
\hline \multirow{2}{*}{\multicolumn{4}{|c|}{ Symptoms }} \\
\hline & & & \\
\hline Burning & 10 & & \\
\hline Dysaesthesiac & 9 & & \\
\hline Shooting & 4 & & \\
\hline Frostbite & 2 & & \\
\hline \multicolumn{4}{|l|}{ Associations: } \\
\hline Numbness & 20 & 8 & \\
\hline Paraesthesiae & 17 & 7 & \\
\hline Weakness & 0 & 5 & 0.02 \\
\hline Moving toes & 3 & 0 & \\
\hline Back pain & 1 & 0 & \\
\hline \multicolumn{4}{|l|}{ Onset: } \\
\hline $0-2$ Weeks & 3 & 0 & \\
\hline 2-4 Weeks & 13 & 0 & \\
\hline 4-8 Weeks & 4 & 1 & \\
\hline$\geqslant 8$ Weeks & 0 & 8 & 0.001 \\
\hline \multicolumn{4}{|l|}{ Site: } \\
\hline Toes & 2 & 0 & \\
\hline Feet & 18 & 9 & \\
\hline \multirow[t]{2}{*}{ Fingers } & 3 & 5 & $0 \cdot 04$ \\
\hline & Signs & & \\
\hline Wasting (distal) & 5 & 4 & \\
\hline Weakness (distal) & 5 & 6 & $0 \cdot 05$ \\
\hline \multicolumn{4}{|l|}{ Ankle reflex: } \\
\hline Normal & 10 & 2 & \\
\hline Impaired & 5 & 2 & \\
\hline Absent & 5 & 5 & \\
\hline \multicolumn{4}{|l|}{ Sensory: } \\
\hline \multicolumn{4}{|l|}{ Cotton wool: } \\
\hline Altered & 20 & 8 & \\
\hline Lost & 13 & 4 & \\
\hline \multicolumn{4}{|l|}{ Pinprick: } \\
\hline Altered & 20 & 8 & \\
\hline Lost & 14 & 3 & \\
\hline Vibration sense & 15 & 7 & \\
\hline Proprioception & 6 & 2 & \\
\hline Temperature & 15 & 8 & \\
\hline \multicolumn{4}{|c|}{ Upper level of sensory signs: } \\
\hline Toe & 2 & 1 & \\
\hline Midfoot & 4 & 0 & \\
\hline Ankle & 10 & 5 & \\
\hline Midshin or above & 4 & 2 & \\
\hline Fingers & 3 & $\overline{5}$ & $0 \cdot 04$ \\
\hline \multirow{2}{*}{\multicolumn{4}{|c|}{ Progress }} \\
\hline & & & \\
\hline Resolved & 6 & & \\
\hline Improved & 9 & & \\
\hline Persisted & 5 & & \\
\hline Deteriorated & 0 & & \\
\hline \multicolumn{4}{|l|}{ Ankle reflex: } \\
\hline Reduced & 6 & 1 & \\
\hline Lost & 9 & 0 & \\
\hline \multicolumn{4}{|l|}{ Sensory loss: } \\
\hline Improved & 2 & 1 & \\
\hline Stable & 10 & 4 & \\
\hline Deteriorated & 8 & 4 & \\
\hline
\end{tabular}

Cerebrospinal fluid.

Cerebrospinal fluid was studied in 12 patients. All had five or less white cells, the protein concentration was raised in seven (mean 0.71 (range $0.2-1 \cdot 3$ ) $\mathrm{g} / \mathrm{l}$ ), in four to over $1 \mathrm{~g} / 1$.

\section{Electrophysiology}

Table 4 shows that the reduction in the sensory nerve action potentials was greater in the legs than in the arms. Sensory conduction velocities were significantly lower than in neurologically asymptomatic AIDS patients. Motor action potentials in the ulnar nerve did not differ from those in this control group. The common peroneal compound muscle action potential was significantly smaller. Distal motor latencies of the common peroneal were slightly prolonged. There was no difference in the ulnar nerve distal motor latency. The $\mathrm{F}$ waves in extensor digitorum brevis were not recordable in $46 \%$ of patients with PPN, but when recordable the latency was no different from that in controls. The patients with myelopathy were comparable electrophysiologically to those without.

\section{Pathology}

Pathological study of eight sural nerves revealed no inflammation with degenerating fibres and a reduced myelinated fibre density (mean(SD) 4396 (931); fig 1). This is lower than the myelinated fibre density in the five neurologically asymptomatic AIDS patients (5 454 (631); $\mathrm{p}=0 \cdot 06$ ). The neurologically asymptomatic AIDS patients had a mean reduction in fibre density of $30.5 \%$ compared to the sudden death controls (mean(SD) fibre density 7845 (1414)). Axonal atrophy was found in the myelinated fibres in nerves from all eight patients with painful peripheral neuropathy studied qualitatively (figs 1 and 2) and in the four of them studied quantitatively. ${ }^{6}$ There were clusters of Schwann cell processes with a few unmyelinated axons suggesting unmyelinated axon loss (mean(SD) density 22280 (3022)). This was not significantly different from density in the five (neurologically asymptomatic AIDS patients (22 006 (2357)). The unmyelinated fibre densities were lower than in the sudden death controls (30 900 (7117)) but this did not reach statistical significance. These results have been reported in detail elsewhere. ${ }^{6}$

\section{Associations}

A study of the first 12 of these patients with PPN revealed a temporal relation with cytomegalovirus infection with $75 \%$ having previous or current cytomegalovirus infection compared to $37 \%$ in the control group of sequential admissions who had AIDS of similar severity, as assessed by duration of infection and CD4 counts (table $1 ; \mathrm{p}<0.05){ }^{8}$ This association held when all 25 patients were considered; the rate then was $78 \%$ or $80 \%$. In the 13 further cases, eight had clear evidence of cytomegalovirus infection (retinitis in three, colitis in two, pneumonitis in two, and oesophagitis in one); in three treatment for cytomegalovirus infection had been started, partly on the basis of PPN. Of these last three patients, two had PCP negative pneumonia with CMV and no other pathogens found in induced sputum, and one (who declined biopsy) had a herpes simplex virus negative perianal ulcer. Thus, the rate of cytomegalovirus infection was $80 \%$ in all cases and $78 \%$ if the last three were excluded. The rate of other infections did not differ from a control group of sequential admissions nor from that found in neurologically asymptomatic controls (table 2). ${ }^{8}$

The serum B-12 concentration in patients with PPN did not differ from that in the neurologically asymptomatic AIDS patients who were at a similar stage in the disease. Only $8.3 \%$ had abnormal concentrations of $\mathrm{B}_{12}$, and the albumin concentrations were similar to the neurologically asymptomatic group (table 1 ). 
Table 4 Nerve conduction studies in peripheral neuropathies in AIDS patients and control groups. Values are means (SD) or [median (interquartile range)]

\begin{tabular}{|c|c|c|c|c|}
\hline & \multicolumn{2}{|c|}{ Patients with peripheral neuropathy } & \multicolumn{2}{|l|}{ Controlst } \\
\hline & $P P N^{\prime}(n=23)$ & $O P N^{\circ}(n=1.3)$ & $\begin{array}{l}\text { Neurologically } \\
\text { asymptomatic } \operatorname{AIDS}(n=30)\end{array}$ & Normal $(n=2.3)$ \\
\hline \multicolumn{5}{|c|}{$\begin{array}{l}\text { Sensory conduction: } \\
\text { Sensory nerve action potential }(\mu \mathrm{V})\end{array}$} \\
\hline $\begin{array}{l}\text { Ulnar } \\
\text { Median } \\
\text { Sural }\end{array}$ & $\begin{array}{l}9 \cdot 4(4 \cdot 5)^{\star} \\
12 \cdot 2(6 \cdot 2)^{\star} \\
{[1 \cdot 0(0-4)]^{\star \star}}\end{array}$ & $\begin{array}{l}6 \cdot 5(3 \cdot 5)^{\star \star} \\
11 \cdot 3(6 \cdot 4)^{\star} \\
{[0 \cdot 8(0-2 \cdot 6)]^{\star \star}}\end{array}$ & $\begin{array}{l}12 \cdot 0(4 \cdot 2) \\
17 \cdot 5(6 \cdot 6) \\
9 \cdot 9(3 \cdot 5)\end{array}$ & $\begin{array}{l}15 \cdot 4(6 \cdot 0) \\
22 \cdot 1(8 \cdot 4) \\
15 \cdot 0(4 \cdot 5)\end{array}$ \\
\hline \multicolumn{5}{|c|}{$\begin{array}{l}\text { Motor conduction: } \\
\text { Compound muscle action potential }(\mathrm{mV})\end{array}$} \\
\hline $\begin{array}{l}\text { Ulnar } \\
\text { Common peroneal }\end{array}$ & $\begin{array}{l}9 \cdot 4(3 \cdot 9) \\
{[1 \cdot 4(0 \cdot 6-2 \cdot 0)]^{\star \star}}\end{array}$ & $\begin{array}{l}10.0(2.4) \\
{[0.7(0-1.5)]^{\star \star}}\end{array}$ & $\begin{array}{r}10 \cdot 5(2 \cdot 6) \\
3 \cdot 7(2 \cdot 0)\end{array}$ & $\begin{array}{l}14 \cdot 4(2 \cdot 8) \\
5 \cdot 7(2 \cdot 8)\end{array}$ \\
\hline $\begin{array}{l}\text { Distal motor latency (ms) } \\
\text { Ulnar } \\
\text { Common peroneal }\end{array}$ & $\begin{array}{l}3 \cdot 1(0 \cdot 8) \\
5 \cdot 4(1 \cdot 2)^{\star}\end{array}$ & $\begin{array}{l}3 \cdot 2(0 \cdot 7)^{\star} \\
6 \cdot 3(1 \cdot 8)^{\star}\end{array}$ & $\begin{array}{l}2 \cdot 8(0 \cdot 7) \\
4 \cdot 6(0 \cdot 7)\end{array}$ & $\begin{array}{l}2 \cdot 7(0 \cdot 4) \\
4 \cdot 5(0.8)\end{array}$ \\
\hline $\begin{array}{l}\text { Motor conduction velocity ( } \mathrm{m} \\
\text { Ulnar } \\
\text { Common peroneal }\end{array}$ & $\begin{array}{l}52 \cdot 2(8 \cdot 0)^{\star \star} \\
36 \cdot 6(5 \cdot 1)^{\star \star}\end{array}$ & $\begin{array}{l}51 \cdot 3(4 \cdot 8)^{\star \star} \\
34 \cdot 2(4 \cdot 7)^{\star \star}\end{array}$ & $\begin{array}{l}57.3(4.9) \\
43.9(5.0\end{array}$ & $\begin{array}{l}60 \cdot 2(4 \cdot 7) \\
49 \cdot 8(4 \cdot 8)\end{array}$ \\
\hline $\begin{array}{l}\text { F waves }(\mathrm{m} / \mathrm{s}) \\
\text { Abductor digiti minimi } \\
\text { Extensor digitorum brevis }\end{array}$ & $\begin{array}{l}68 \cdot 0(7 \cdot 0) \\
35 \cdot 2(5 \cdot 5)\end{array}$ & $\begin{array}{l}67 \cdot 3(6 \cdot 1) \\
30 \cdot 2(2 \cdot 5)^{\star \star}\end{array}$ & $\begin{array}{l}70 \cdot 2(5 \cdot 5) \\
36 \cdot 6(3 \cdot 9)\end{array}$ & $\begin{array}{l}73.9(4.9) \\
+2.3(3.8)\end{array}$ \\
\hline
\end{tabular}

${ }^{\star} p=0.05-0.01,{ }^{\star} p<0.01 ;$ comparison with neurologically asymptomatic controls. †A comparison of normal controls with neurologically asymptomatic AIDS patients has been published : tF-waves corrected according to formula: height (F-wave latency rologically asymptomatic AIDS patients has been published. $\$$ F-waves corrected according to formula: height (F-Ware latency-
$M$-wave latency - 1). PPN $=$ painful peripheral neuropathy; OPN $=$ other (non-painful) peripheral neuropathies. SAP = Sensory nerve action potential, CMAP = Compound muscle action potential, DML = Distal motor latency, $\mathrm{MCV}=$ Motor conduction nerve action potential, $\mathrm{CMAP}=\mathrm{Compound}$ muscle action potential, $\mathrm{DML}$
velocity, $\mathrm{ADM}=$ Abductor digiti minimi, $\mathrm{EDB}=$ Extensor digitorum brevis

OTHER PERIPHERAL NEUROPATHIES

The characteristics of the 13 patients with non-painful neuropathies (OPN) are given in table 1 ; the preceeding infections are given in table 2. The severity of AIDS in these neuropathies was not significantly different from either of the control groups, nor from patients with painful neuropathies.

\section{Clinical features}

Six patients had sensorimotor neuropathies, four had additional bilateral upper motor neuron signs, and three had purely sensory neuropathies. Five of the patients had symp- toms or signs in both arms and legs; in four the symptoms were limited to the legs. Three patients had clinical evidence of super-added mononeuropathies. Eight of the patients complained of numbness, seven of paraesthesia, and five of weakness. The onset of the neuropathy was insidious, in most patients coming on over two months, in one possibly over years. Focal wasting distally was found in four patients; in six there was distal weakness. Ankle reflexes were absent in five patients, impaired in two, normal in two. Superficial sensation was altered in all but one patient, being limited to the toes in one,
Figure 1 One micron araldite sections of sural nerve $\times$ 470. (a) From a patient with painful peripheral neuropathy: there is a reduced density of fibres; many fibres are atrophic and a few are degenerating (arrows) (b) from a patient with non-painful peripheral neuropathy: the fibre density is reduced and degenerating fibres are seen (arrows); (c) control nerve.

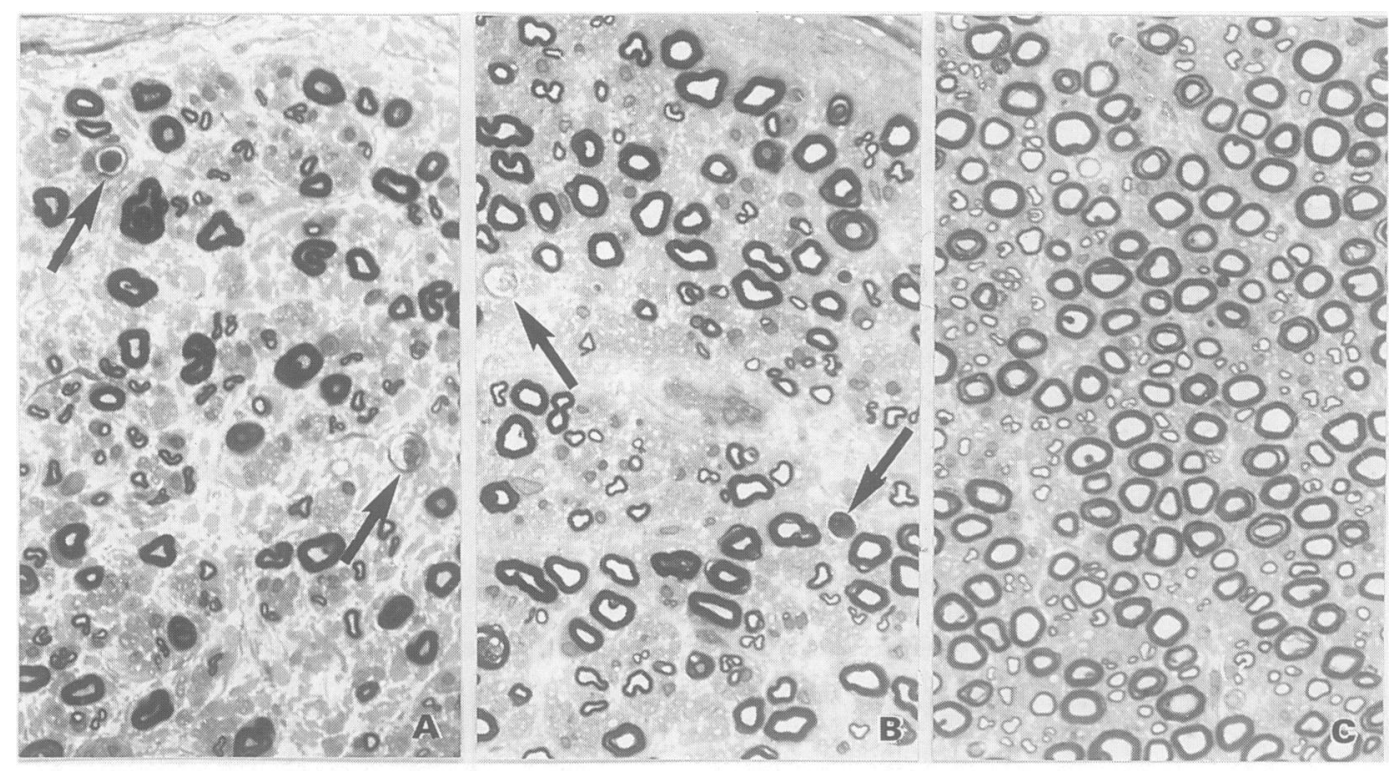




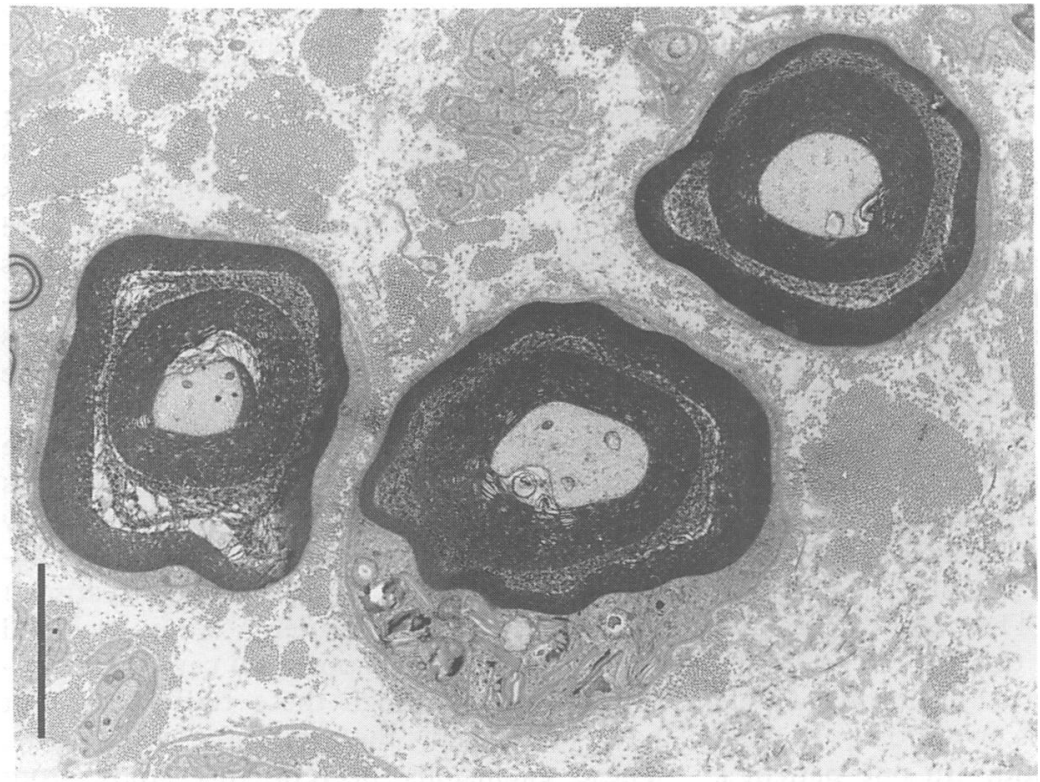

Figure 2 Electron micrograph of sural nerve from patient with painful peripheral neuropathy, showing three atrophic myelinated fibres with axons that are small relative to myelin sheath thickness. Bar $=5 \mu \mathrm{m}$.

the foot in five, and the knees in two. Sensory loss in the fingers was found in five patients; posterior column loss was found in seven. The symptoms and signs of the neuropathy were progressive in four patients, static in four, and apparently improved in one. Two patients had pes cavus. Four patients with myelopathy and neuropathy had similar clinical pictures.

Twelve patients were followed until death (median 8 months, range 1-17 months); one was reviewed nine months after onset of symptoms.

\section{Electrophysiology}

Table 4 summarises the electrophysiology findings. Sensory nerve action potentials were reduced, more in the legs than in the arms. Sensory conduction velocities were significantly reduced when compared with those in neurologically asymptomatic AIDS patients. Motor action potentials in the ulnar nerve did not differ from those in this control group. The common peroneal compound muscle action potential was significantly smaller. Distal motor latencies of the common peroneal were slightly prolonged. There was no difference in the ulnar nerve distal motor latency. The $\mathrm{F}$ waves in extensor digitorum brevis were not recordable in $46 \%$ of the patients, although when they were recordable the latency was no different from that in the control group. The patients with myelopathy were comparable electrophysiologically to those without.

\section{Cerebrospinal fluid}

Cerebrospinal fluid was acellular in all patients studied. Four out of five patients had raised concentrations of protein (mean 0.84 $\mathrm{g} / \mathrm{l}$, range $0 * 4-1 \cdot 7 \mathrm{~g} / \mathrm{l})$.

\section{Pathology}

Pathological findings have been reported in detail elsewhere. ${ }^{6}$ There was evidence of myelinated fibre loss with degenerating fibres (fig 1) but no evidence of axonal atrophy in three sural nerves studied quantitatively. ${ }^{6}$ Mean (SD) myelinated fibre density was 4796 (414) and unmyelinated fibre density was 22475 (5043).

None of the five sural nerves of neurologically asymptomatic AIDS patients with subclinical neuropathy ${ }^{7}$ showed axonal atrophy qualitatively, nor was it found in one nerve studied quantitatively. ${ }^{6}$

\section{Associations}

Two associations were noted. Firstly, the body mass index was significantly lower than in either the asymptomatic AIDS controls $(p<0.005)$ or in patients with painful peripheral neuropathy $(p<0.02)$ (table 1$)$. Secondly, Mycobacterium avium intracellulare infection was more common than in a group of sequential AIDS controls (4/13 $v 1 / 30 ;^{8} \mathrm{p}$ $<0.03)$. The rate of other infections did not differ from that in the neurologically asymptomatic or sequential admission AIDS control groups (table 2). A total of $31 \%$ of these patients had abnormal concentrations of $\mathbf{B}_{12}$, a slightly higher rate, though not significantly so, than in the neurologically asymptomatic AIDS group.

\section{MONONEURITIS MULTIPLEX}

One patient aged 57 with AIDS related complex presented with a rapidly progressive monoplegia associated with pneumococcal pneumonia. He was positive for hepatitis $B$ surface antigen. He deteriorated rapidly and at necropsy a large vessel vasculitis of the femoral nerve was found.

Two patients were seen with mononeuritis multiplex related to lymphoma. One aged 41 presented with fevers and weight loss together with a right femoral neuropathy. Hepatic ultrasound showed multiple lesions. He died shortly after investigation and was found to have a non-Hodgkin $B$ cell lymphoma in nodes and liver. Lymphoma was found infiltrating his femoral nerve (fig 3). Another

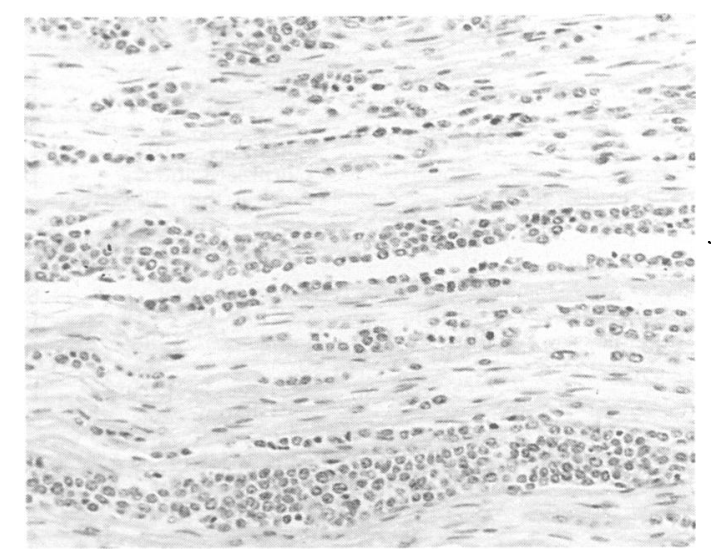

Figure 3 Paraffin section $(\times 140)$ of femoral nerve showing infiltration of the endoneurium by columns of lymphoma cells. 
patient, aged 34, presented with multiple cranial nerve palsies and a cervical radiculopathy and was found to have lymphomatous meningitis.

ISOLATED MONONEUROPATHIES

Three patients with isolated mononeuropathies had AIDS related complex and eight had AIDS. Their mean (SD) age was $41 \cdot 1(6 \cdot 7)$ years. The patients with AIDS related complex had a median CD4 count of $160 / \mu 1$ and a mean body mass index of $26 \cdot 6$. Those with AIDS had a median CD4 count of $55 / \mu 1$ and a body mass index of $21 \cdot 6$. The nerve most commonly affected was the lateral cutaneous nerve of the thigh $(n=5)$, followed by the common peroneal $(n=3)$ and median $(n=3)$ nerves. The neuropathies presented usually either during or after the patients had been admitted to hospital (7/11) for a variety of infections or tumours. In most no local cause was found. In one patient a meralgia paraesthetica occurred at the same time and side as inguinal lymphadenopathy due to lymphoma; it resolved with treatment of the lymphoma. In a further seven patients the mononeuropathy resolved spontaneously. In three (one with meralgia paraesthetica, one common peroneal and one median), the symptoms persisted.

Results of electrophysiological studies in nerves other than those affected clinically did not differ from those in neurologically asymptomatic AIDS patients.

\section{POLYRADICULOPATHY}

Two patients with lumbosacral polyradiculopathy have been reported in detail elsewhere. ${ }^{9}$

\section{Discussion}

We have described the range of peripheral nerve syndromes seen in a 15 month period in a relatively stable outpatient population of HIV positive patients at various stages of their disease. As the population was known at two points, an estimate of the population halfway through the study can be obtained and this can be used to estimate the 15 month incidence of the various syndromes (table 5). Painful peripheral neuropathy was the most common, occurring in $7 \cdot 5 \%$ of AIDS patients; non-painful peripheral neuropathies were seen in $4 \%$. Mononeuropathy occurred in $3 \%$ of AIDS patients, and mononeuritis multiplex and a lumbosacral polyradiculopathy were each seen in $0.6 \%$. Neuropathies during the AIDS related complex stage occurred in fewer than $1 \%$ of patients.

These estimates contain several possible sources of inaccuracy. Firstly, the patients may not have been referred to the neurology service. Secondly, the population was changing and patients may have sought treatment elsewhere. Thirdly, patients were excluded when they had other potential causes for neuropathy, even though these causes may not have produced the relevant neuropathy. These exclusions prevent this study from assessing whether pre-existing neuropathy predisposes to the development of PPN.

In table 5 the incidence and relative rates of different patterns of neuropathies are compared with those of other unselected series, including case series, prevalence studies, and a point prevalence study. In all studies, distal symmetrical peripheral neuropathies were the most common and account for some $90 \%$ of all neuropathies in AIDS. In early series they were estimated to affect $2-5 \%$ of AIDS patients. ${ }^{1011}$ In a study comparable to ours from Baltimore, ${ }^{12} 13 \%$ of AIDS patients had distal symmetrical peripheral neuropathies. In our series, lumbosacral polyradiculopathy and mononeuritis multiplex each were found in fewer than $1 \%$ of patients with AIDS and AIDS related complex.

Other researchers have described a syndrome similar to painful peripheral neuropathy, usually grouped together with non-painful neuropathies, as "predominantly sensory neuropathy," "sensory motor neuropathy," "distal symmetrical polyneuropathy," or "painful neuropathy". 12-15 When the clinical features were similar to those

Table 5 Series of peripheral neuropathies of six or more cases

\begin{tabular}{|c|c|c|c|c|c|c|c|c|}
\hline Author year & Centre & Population & $D S P N^{\circ}$ & $C I D P$ & $A I D P$ & $M I M I$ & $L S P R$ & $M N^{\circ}$ \\
\hline Snider et al, 1983" & New York & 160 AIDS & $8(5 \%)$ & & & & & \\
\hline Levy et al, 1985" & $\begin{array}{l}\text { San } \\
\text { Francisco }\end{array}$ & $\begin{array}{l}318 \text { AIDS or } \\
\text { ARC }\end{array}$ & $\begin{array}{l}5(2 \%) \\
2\end{array}$ & & & $9(3 \%)$ & & \\
\hline Guiloff et al, 1988 & London & 122 AIDS & $4(3 \%)$ & & & $1(0.8 \%)$ & $1(0 \cdot 8 \%)$ & \\
\hline $\begin{array}{l}\text { Cornblath and } \\
\text { McArthur, 1988': }\end{array}$ & Baltimore & $\begin{array}{l}\text { Est } 200 \text { AIDS } \\
\text { ? ARC } \\
\text { ? HIV + }\end{array}$ & $26(13 \%)$ & $\begin{array}{l}1(0 \cdot 5 \%) \\
\frac{1}{7}\end{array}$ & 3 & 2 & & \\
\hline${ }^{\star \star}$ Miller et al, 1988" & $\begin{array}{l}\text { San } \\
\text { Francisco }\end{array}$ & NS & 18 & 10 & & 2 & 3 & \\
\hline †So et al, 1988 & $\begin{array}{l}\text { San } \\
\text { Francisco }\end{array}$ & 40 AIDS & $13(33 \%)$ & & & & & \\
\hline Lange et al, $1988^{\prime}$ & New York & $\begin{array}{l}\text { NS AIDS } \\
\mathrm{HIV}+\end{array}$ & 8 & 2 & & $\begin{array}{l}1 \\
1\end{array}$ & & \\
\hline $\begin{array}{l}\star \star \star \text { Leger et al, } 1989^{23} \\
\star \star \star \text { Chaunu et al, } 1989^{\prime \prime}\end{array}$ & Paris & $\begin{array}{l}\text { NS AIDS } \\
\text { ARC } \\
\text { HIV + }\end{array}$ & $\begin{array}{r}15 \\
8\end{array}$ & $\begin{array}{l}1 \\
3 \\
5\end{array}$ & 1 & $\begin{array}{l}1 \\
1\end{array}$ & 1 & \\
\hline This series & London & $\begin{array}{l}331 \text { AIDS } \\
763 \text { ARC } \\
565 \text { HIV + }\end{array}$ & $38(11.5 \%)$ & & & $\begin{array}{l}2(0.6 \%) \\
1(0.1 \%)\end{array}$ & $2(0 \cdot 6 \%)$ & $\begin{array}{l}8\left(3 \cdot 0^{\prime \prime}{ }^{\prime \prime}\right) \\
3\left(0 \cdot 4^{\prime \prime} 1\right)\end{array}$ \\
\hline
\end{tabular}

DSPN = Distal symmetrical peripheral neuropathy. CIDP = Chronic inflammatory demyelinated polvradiculoneuropathr. AIDP $=$ Acute inflammatory demyelinating polyradiculoneuropathy. $\mathrm{MM}=$ Mononeuritis multiplex. LSPR = Lumbosacral polyradicu= Acute inflammatory demyelinating polyradiculoneuropathy. $\mathrm{MM}=$ Mononeuritis multiplex. LSPR = Lumbosacral polyradicu-
lopathy. $M N=$ Mononeuropathies. NS = not stated. ARC = AIDS related complex. Percentages of given populations are in lopathy. MN $=$ Mononeuropathies. NS $=$ not stated. ARC $=$ AIDS related complex. Percentages of given popt
brackets. ${ }^{\star \star}$ not classified by disease stage. ${ }^{\star \star \star} 2$ overlapping series combined. + Limited to hospitalised patients. 
described here, pain was reported in about $60 \%$ of patients, in all limited to the feet. Complaints of weakness are uncommon. Mild distal weakness was found in some and the ankle reflexes were usually lost or impaired. Sensory loss was usually mild, most often affecting vibration sense and pinprick and often associated with contact dysaesthesia. ${ }^{12}$ Previous reports have noted that the pain has remained prominent, ${ }^{15}$ although the neuropathy has progressed. ${ }^{12}$ In $75 \%$ of our patients with painful peripheral neuropathy the pain improved or resolved and patients required less analgesia or pain modulating agents such as tricyclics or carbamazepine. The sensory loss remained stable or improved in $60 \%$, although there was a progressive loss of ankle reflexes. Several possible explanations might account for these different descriptions: the entities may differ in some fashion; patients who improve tend to be lost to follow up and this may eschew some series with limited follow up; and the treatment with anti-cytomegalovirus drugs may alter the clinical course of the syndrome.

Defining painful peripheral neuropathy on the basis of a single subjective clinical symptom poses several difficulties. Firstly, individuals' pain thresholds vary. Secondly, in the setting of HIV disease, central nervous system disorders such as myelopathy and encephalopathy may modulate the pain. Thirdly, the pain might result from more than one peripheral nerve pathology in AIDS.

In this study, as in our earlier report, ${ }^{8}$ active cytomegalovirus infection was found in $80 \%$ of patients with painful peripheral neuropathy as compared to $37 \%$ of sequential unselected controls who were at a similar stage of the disease and who were assessed in the same way as patients with neuropathy. This should have removed any diagnostic bias in identifying cytomegalovirus. The virus is known to be an important pathogen in AIDS related lumbosacral polyradiculopathy ${ }^{16}$ and in a multifocal sensory motor neuropathy associated with AIDS. ${ }^{17}$ On the basis of the clinical syndrome, we suggested that the pain in painful peripheral neuropathy may be related to a dorsal root ganglionitis, ${ }^{8}$ and, indeed, several case reports have found a dorsal root ganglionitis at necropsy. ${ }^{1819}$

The electrophysiological findings in this series of patients with distal symmetrical peripheral neuropathy mirrored those from previous studies. ${ }^{1012-15}$ Sensory action potentials were considerably reduced, especially in the legs, with a mild reduction of motor conduction velocities and compound muscle action potentials. The $F$ waves have been reported as being prolonged, ${ }^{15}$ although the comparison was with normal controls rather than asymptomatic AIDS patients. Using such AIDS patients as controls, we found no difference. The findings were similar in painful and other peripheral neuropathies and consistent with axonopathy. The velocities were reduced but to a lesser degree than the amplitude of sensory motor action potentials, suggesting that demyelination is not a major pathology. This is supported by the $F$ wave velocities not differing from those in our neurologically asymptomatic AIDS controls. Axonal loss was found in all our cases of distal symmetrical peripheral neuropathy and has been consistently reported by others. ${ }^{1315}$ 20-21 Myelinated fibre densities were reduced to a similar degree in this and other studies. ${ }^{21}$ ${ }_{23}$ The myelinated fibre density in patients with PPN was $20 \%$ lower than that in neurologically asymptomatic controls but no different from that in patients with OPN. The density of unmyelinated axons was the same as in the asymptomatic controls (22 $260 v 22$ 016). The unmyelinated fibre density and the unmyelinated axon density of the patients with non-painful peripheral neuropathies were similar to those of patients with painful neuropathies.

The only morphological finding that distinguished patients with a painful peripheral neuropathy from those with other peripheral neuropathies and the neurologically asymptomatic AIDS controls was axonal atrophy. Qualitatively, this was found in all eight sural nerves of patients with painful neuropathies but not in eight nerves of patients with nonpainful neuropathies. Quantitatively, it was seen in all four patients with painful neuropathies studied but in none of the three patients with non-painful distal symmetrical neuropathies nor in any neurologically asymptomatic AIDS patients. ${ }^{\circ}$ A two tailed Fisher's exact test on these data rejects the null hypothesis of independence between PPN and axonal atrophy $(p<0.03) .^{\circ}$ There was no concomitant atrophy of unmyelinated axons. ${ }^{6}$

These findings can be interpreted in several ways. Firstly, it can be speculated that the subclinical peripheral neuropathy found in neurologically asymptomatic AIDS, the other non-painful neuropathies, and the painful peripheral neuropathy in AIDS represent different points in a continuous spectrum. The significantly longer duration of OPN than PPN at presentation (table 3 ) is against the idea that a non-painful neuropathy progresses to a point when it becomes painful. Alternatively, the painful and the non-painful peripheral neuropathies may represent distinct entities which occur in the setting of a non-specific "axonal loss of chronic disorders." Evidence of this loss in our study on AIDS related subclinical peripheral neuropathy, ${ }^{\top}$ the relatively stereotyped clinical presentation of PPN, and the findings of associated axonal atrophy and CMV infection in PPN would all point to PPN as a distinct entity rather than as part of a continuum and raise the question as to whether it should represent a subdivision in DSPN. ${ }^{2+}$

The non-painful distal symmetrical peripheral neuropathies reported here seemed to be more heterogeneous than PPN and two patients had pes cavus, suggesting an inherited neuropathy despite the lack of a family history. In addition, this group had a significantly lower body mass index, suggesting a possible role for nutritional factors. 
These patients also had an increased incidence of Mycobacterium avium intracellulare infection, suggesting a possible role for this agent, which has been found in peripheral nerve. ${ }^{25}$ Vitamin $B_{12}$ was found to be abnormal in $31 \%$ of these patients compared with $24 \%$ of the neurologically asymptomatic controls, but this difference did not reach significance. These associations must be treated with caution in the context of multiple statistical comparisons made between the two groups.

Chronic inflammatory demyelinating polyradiculopathy was reported in only two patients with AIDS in any series (table 5). Eighteen cases have been reported in patients with AIDS related complex or asymptomatic HIV patients, nearly half from one centre. ${ }^{26} \mathrm{~A}$ further 10 were reported from another centre, but the disease stage was not specified. ${ }^{14}$ We saw no cases in over a thousand patients during a 15 month period. No cases were reported in a point prevalence study of HIV positive men. ${ }^{1}$ Chronic inflammatory demyelating polyradiculopathy during the AIDS, AIDS related complex, and HIV seropositivity stages must therefore be recognised as rare.

The Guillain-Barré syndrome is rare; only four patients were reported in non-selective population studies (table 5). There are case reports of acute inflammatory demyelinating polyradiculopathy (AIDP) after seroconversion for $\mathrm{HIV}^{2 i}{ }^{28}$ as for other types of infection. ${ }^{29}$ In a selective series from Zimbabwe, $59 \%$ of 29 consecutive patients with AIDP were found to be HIV positive, ${ }^{30}$ but seroconversion and asymptomatic HIV positivity were not distinguished. The expected rate of co-occurrence of AIDP in asymptomatic HIV seropositivity by chance is $\mathbf{5 - 3 0}$ cases a year (1-2/100 000 population per year ${ }^{31}$ in an estimated population of $0.5-1.5$ million..$^{32} \mathrm{~A}$ definite association between AIDP and asymptomatic HIV seropositivity rather than seroconversion must wait for definitive confirmation. The chronic condition is much rarer than the acute form but accurate incidence figures are not available; it may therefore be assumed that the association with HIV seropositivity is real.

Mononeuritis multiplex was also a rare pattern of peripheral nerve involvement in our study, secondary to lymphoma during AIDS and vasculitis during AIDS related complex. Infiltration of the peripheral nerve by lymphoma is well recognised in HIV negative lymphomas and in one retrospective pathological series was found in $40 \%$ of 145 cases of lymphoma. ${ }^{33}$ It has been reported sporadically in AIDS. ${ }^{3+}$

The most frequent isolated mononeuropathy was that involving the lateral cutaneous nerve of the thigh. This syndrome is common in men in their 30 s and 40 s, and cases are often identified only on direct questioning. ${ }^{35}$ This suggests that this presentation may have been a reflection of heightened awareness of physical symptoms in patients with AIDS related complex and AIDS. The other mononeuropathies seen affected nerves that are often involved at entrapment sites, particularly in patients who have lost weight. ${ }^{36}$

Distal symmetrical peripheral neuropathies account for $90 \%$ of neuropathies seen in AIDS. The aetiopathogenesis of these syndromes is currently poorly understood. The form of painful peripheral neuropathy seen in the AIDS patients described here seems to be a distinct clinical entity and may have a specific aetiopathogenesis. Further detailed pathological studies of these patients are needed.

We thank Drs B G Gazzard, A Lawrence, and D Hawkins for allowing us to study patients under their care, $\mathrm{Dr} J \mathrm{~N}$ allowing us to study patients under their care, Dr $\mathrm{N}$ Harcourt-Webster for access to postmortem material, and
Miss J Roberts for secretarial assistance. GNF was an MRC Miss J Roberts for secretarial assistance. GNF was an MRC
research training fellow; this work formed part of an MD thesis submitted to the University of London. We received finan cial support from the Special Trustees of Westminster and Roehampton Hospitals.

1 McArthur JC, Cohen BA, Selnes OA, Kumar AJ, Cooper $\mathrm{K}$, McArthur JH, et al. Low prevalence of neurological and neuropsychological abnormalities in otherwise healthy HIV-1-infected individuals: results from the healthy HIV-1-infected individuals: results from the multicenter A

2 So YT, Holtzman DM, Abrams DI, Olney RK. Peripheral neuropathy associated with acquired immunodeficiency syndrome. Prevalance and clinical features from a population-based survey. Arch Neurol 1988;45:945-8.

3 Fuller GN. The peripheral nervous system in HIV infection: a clinical, electrophysiological and pathologica study [dissertation]. London: University of London, 1990.

4 Centers for Disease Control. Revision of the CDC surveillance case definition for acquired immunodeficiency lance case definition for acquired

5 Jacobs JM, Love S. Qualitative and quantitative morphol ogy of human sural nerve at different ages. Brain ogy of human sural

6 Fuller GN, Jacobs JM, Guiloff RJ. Axonal atrophy in the painful peripheral neuropathy in AIDS. Acto Neuropathologica 1990;81:198-203.

7 Fuller GN, Jacobs JM, Guiloff RJ. Subclinical peripheral nerve involvement in AIDS: an electrophysiological and pathological study. $f$ Neurol Neurosurg Psychiatry 1991;54:318-24.

8 Fuller GN, Jacobs JM, Guiloff RJ. Association of painful peripheral neuropathy in AIDS with cytomegalovirus infection. Lancet 1989;ii:937-41.

9 Fuller GN, Gill SK, Guiloff RJ, Kapoor R, Lucas SB Sinclair E, et al. Ganciclovir for lumbosacral polyradiculopathy in AIDS. Lancet 1990;335:48-9.

10 Snider WD, Simpson DM, Nielsen S, Gold JW, Metroka CE, Posner JB. Neurological complications of the acquired immune deficiency syndrome: analysis of 50 patients. Ann Neurol 1983;14:403-18.

1 Levy RM, Bredesen DE, Rosenblum ML. Neurologica manifestations of the acquired immunodeficiency syndrome (AIDS): experience at UCSF and review of the literature. $\mathcal{f}$ Neurosurg 1985;62:475-95.

12 Cornblath DR, McArthur JC. Predominantly sensory neuropathy in patients with AIDS and AIDS-related complex. Neurology 1988;38:794-6.

13 Bailey RO, Baltch AL, Venkatesh R, Singh JK, Bishop MB. Sensory motor neuropathy associated with AIDS Neurology 1988;38:886-91.

14 Miller RG, Parry GJ, Pfaeffl W, Lang W, Lippert R, Kiprov D. The spectrum of peripheral neuropathy associated with ARC and AIDS. Muscle and Nerve 1988;11:857-63.

5 Lange DJ, Britton CB, Younger DS, Hays AP. The neuromuscular manifestations of human immunodeficiency virus infections. Arch Neurol 1988;45:1084-8.

16 Miller RG, Storey JR, Greco CM. Ganciclovir in the treatment of progressive AIDS-related polyradiculopathy. Neurology 1990;40:569-74.

17 Said G, Lacroix C, Chemouilli P, Goulon-Goeau C, Roullet E, Penaud D, et al. Cytomegalovirus neuropathy in acquired immunodeficiency syndrome: a clinical and pathological study. Ann Neurol 1991;29:139-46.

18 Robert ME, Geraghty JJ, Miles SA, Cornford ME, Vinters HV. Severe neuropathy in a patient with acquired HV. Severe neuropathy in a patient with acquired
immune deficiency syndrome (AIDS). Evidence for widespread cytomegalovirus infection of peripheral nerve and human immunodeficiency virus-like nerve and human immunodeficiency virus-like
immunoreactivity of anterior horn cells. Acta immunoreactivity of anterior
Neuropathologica 1989;79:255-61.

19 Budzilovich GN, Avitabile A, Niedt G, Aleksic SN, Rosenblum MK. Polyradiculopathy and sensory ganglionitis due to cytomegalovirus in acquired immun deficiency syndrome (AIDS). Progress in Aids Patholog 1989;1:143-57.

20 Berger JR, Sheremata WA, Resnick L, Atherton S, 
Fletcher MA, Norenberg M. Multiple sclerosis-like illFetcher MA, Norenberg $M$. Multiple sclerosis-like illness occurring with human imm

21 Gastaut JL, Gastaut JA, Pellissier JF, Tapko JB, Weill O. Peripheral neuropathies in human immunodeficiency virus infection. A prospective study of 56 patients. Rev Neurol 1989;145:451-9.

22 Chaunu MP, Ratinahirana $H$, Raphael $M$, Henin D, Leport C, Brun-Vezinet F, et al. The spectrum of changes on 20 sural nerve biopsies in patients with HIV Muscle and Nerve 1989;12:452-9.

23 Leger JM, Bouche P, Bolgert F, Chaunu MP, Rosenheim $M$, Cathala HP, et al. The spectrum of polyneuropathies in patients infected with HIV. $\mathcal{f}$ Neurol Neurosurg in patients infected with

24 Working Group of the American Academy of Neurology AIDS Task Force. Nomenclature and research case defAIDS Task Force. Nomenclature and research case definitions for neurologic manifestations of human immun-
odeficiency virus-type 1 (HIV-1) infection. Neurology odeficiency virus-ty

25 Wrzolek MA, Rao C, Kozlowski PB, Sher JH. Muscle and nerve involvement in AIDS patient with disseminated mycobacterium avivum intracellulare infection. Muscle and Nerve 1989;12:247-9.

26 Cornblath DR, McArthur JC, Kennedy PG, Witte AS, Griffin JW. Inflammatory demyelinating peripheral neuropathies associated with human $\mathrm{T}$-cell lymphotropic virus type III infection. Ann Neurol 1987;21:32-40.

27 Piette AM, Tusseau F, Vignon D, Chapman A, Parrot G, Liebowitch $\mathrm{J}$, et al. Acute neuropathy coincident with seroconversion for anti-LAV/HTLV-III. Lancet 1986;i:852.

28 Hagberg L, Malmvall BE, Svennerholm L, Alestig K,
Norkrans G. Guillain-Barré syndrome as an early manifestation of HIV central nervous system infection. Scand f Infect Dis 1986;18:591-2.

29 Winer JB, Hughes RAC, Anderson MJ, Jones DM, Kangro H, Watkins RPF. A prospective study of acute idiopathic neuropathy. II. Antecedent events. $\mathcal{f}$ Neurol Neurosurg Psychiatry 1988;51:613-8.

30 Thornton CA, Latif AS, Emmanuel JC. Guillain-Barre syndrome associated with human immunodeficiency virus infection in Zimbabwe. Neurology 1991;41:812-5.

31 Arnason BGW. Acute inflammatory demyelinating polyradiculoneuropathies. In: Dyck PJ, Thomas PK, Lambert EH, Bunge R, eds. Peripheral neuropathy. Philadelphia: WB Saunders, 1984:2050-100.

32 Moss AR, Becchetti P. Natural history of HIV infection. AIDS 1989;3:55-61.

33 Jellinger K, Radaszkiewicz $\mathrm{T}$. Involvement of the central nervous system in malignant lymphomas. Virchows Archiv 1976:370:345-62.

34 Gold JE, Jimenez E, Zalusky R. Human immunodeficiency virus-related lymphoreticular malignancies and peripheral neurologic disease. A report of four cases. Cancer 1988;61:2318-24.

35 Stephens H. Meralgia paraesthetica. Arch Neurol Psychiatry 1957;77:557-74.

36 Sotaniemi KA. Slimmer's paralysis-peroneal neuropathy during weight reduction. $f$ Neurol Neurosurg Psychiatry 1984;47:564-6.

37 Guiloff RJ, Fuller GN, Roberts A, Hargreaves M, Gazzard $B$, Scaravilli $F$, et al. Nature, incidence and prognosis of neurological involvement in the acquired immuno ciency syndrome in central London. Postgrad Med $₹$ ciency syndrome 